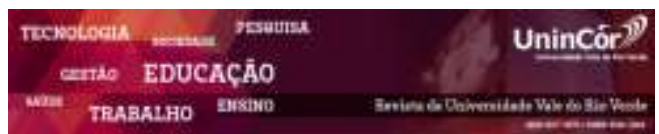

Revista da Universidade Vale do Rio Verde ISSN: 1517-0276 / EISSN: 2236-5362 v. 17 | n. 1 | Ano 2019

Núbia Cristina Rocha Passos Faculdade de Ciências Empresariais - FACEMP nubiapassos@gmail.com.br

Larissa Rolim Borges-Paluch Faculdade Maria Milza - FAMAM larissapaluch@gmail.com

Elizabete Rodrigues da Silva Faculdade Maria Milza - FAMAM betysilvaok@yahoo.com.br

Liliany Santana da Silva Faculdade Maria Milza - FAMAM lilaros2@gmail.com

Cláudia Cecília Blaszkowski de Jacobi Faculdade Maria Milza - FAMAM cbjacobi@gmail.com

\section{VULNERABILITY OF WOMEN LIVING WITH HIV/AIDS IN THE NORTHEAST REGION OF BRAZIL}

\begin{abstract}
Individual and group vulnerabilities of HIV positive people generally result from social, cultural and political factors. The vulnerabilities should be analyzed taking into account the individual and social dimensions, and the policies behind patient care and treatment. Vulnerabilities have three interdependent dimensions: the social, the individual and the programmatic dimension. The aim of this study was to analyze the social, individual and public policy contexts that affect the vulnerabilities of women living with HIV/AIDS in the Recôncavo da Bahia. This was a qualitative and descriptive research, and data were obtained by means of a semi structured interview applied to 26 women that attended the Centro de Testagem Viva Vida. From the women's statements it may be concluded that in terms of social, individual and programmatic vulnerability all of them experienced fear of death, discrimination, stigma and prejudice. It was also observed that with regard to heterosexualization, interiorization, feminization, impoverishment and blackening the disease has in the Recôncavo the same profile it has nationwide.
\end{abstract}

Keywords: Women's health. Vulnerability Study. HIV Infections.

\section{VULNERABILIDADES DE MULHERES VIVENDO COM HIV/AIDS NA REGIÃO NORDESTE DO BRASIL}

\section{RESUMO}

As vulnerabilidades sofridas pelos indivíduos e grupos susceptíveis ou portadores de HIV/Aids são, geralmente, resultantes de fatores sociais, culturais e políticos. Desta forma, as vulnerabilidades devem ser analisadas levando-se em consideração as dimensões relativas ao indivíduo e o local social por ele ocupado, além das questões políticas que envolvem o percurso do atendimento e do tratamento. A análise das vulnerabilidades envolve três planos interdependentes, caracterizando-as como vulnerabilidade social, individual e programática. $\mathrm{O}$ presente estudo teve como objetivo analisar os elementos presentes no contexto social, individual e das políticas públicas que 
configuram as vulnerabilidades de mulheres vivendo com HIV/Aids no Recôncavo da Bahia. A pesquisa é de natureza qualitativa com abordagem descritiva dos dados. O instrumento de coleta foi entrevista semestruturada com 26 mulheres atendidas no Centro de Testagem Viva Vida. Os depoimentos revelaram que nos planos interdependentes das vulnerabilidades social, individual e programática todas as mulheres vivenciam o medo da morte, a discriminação, estigma e o preconceito; e que no Recôncavo a epidemia apresenta o mesmo perfil nacional de heterossexualização, interiorização, feminização, juvenização pauperização e enegrecimento.

Palavras-chave: Saúde da mulher. Estudo sobre Vulnerabilidade. Infecções por HIV.

Recebido em: 07/02/2018 - Aprovado em: 31/03/2019 - Disponibilizado em: 15/07/2019

\section{INTRODUCTION}

The factors that spread the Human Immunodeficiency Virus/Acquired Immunodeficiency Syndrome (HIV/AIDS) epidemic are closely related to the highly hierarchical social organization of genre and sexuality structures (PANARRA et al, 2017).

For Bastos (2000) the central point of the feminization of the HIV/AIDS epidemic is due to genre which determines an unequal treatment of individuals in a macro and micro social dimension that includes political, cultural, social and economic aspects that result in the lack of fundamental rights, unequal power relations and differentiated access to material and symbolic goods.

Those differences are observed in the family, in partnerships and in the society, and are organized according to belief systems and value codes. These inequalities generally have social effects that multiply the risks faced by women. Thus, genre roles might affect behaviors that increase the HIV infection risk or inhibit prevention. According to several authors, male and female sexuality construction reflects inequalities that seriously affect women's vulnerability to HIV infection (PARKER, 2001).

Since the concept of vulnerability establishes relationships between individual illness and social context, it allows to extend health promotion and prevention activities. Moreover, the information and model transmission in order to modify risk behaviors foster a social response that is capable of changing cultural, moral, political and economic aspects that form the basis of risk behaviors (PAIVA et al, 2002).

When we analyze the population under study, the increasing number of contaminated women that have a stable marital relationship reaffirms the need to reflect on the HIV vulnerability self-perception. For knowing about the risks not always determines a behavior change and, besides, if one of the partners is economically dependent on the other, negotiation power in terms of sexual practices is weakened (GUEDES et al, 2009). 
Neves (2009) explain that the HIV/AIDS infection impact on women goes beyond the individual and extends to the whole family due to their organizational role in domestic life. Thus, the objective of this research is to analyze the social, individual and public policy contexts that affect the vulnerability of women living with HIV/AIDS in the Recôncavo da Bahia.

\section{Vulnerability and the interdependent dimensions}

Being vulnerable is lacking the means for self-protection: not having access to health services, education, work, income, housing or the freedom to choose or propose. The word vulnerability was first used in connection with human rights, and later it was adopted by people in the health area working with the HIV infection (BRASIL, 2007).

Mann et al. (1993) developed the concept of vulnerability and established reference patterns to assess HIV infection vulnerability. This concept allows to establish a dialogue between epidemiology and other sciences, and popular knowledge that contributes to find solutions to practical problems and leads to new theoretical compositions.

This concept led to a new understanding about the influence of social, cultural and political factors on the susceptibility of individuals and groups to HIV infection that broadened the guidelines and strategies in order to reduce these vulnerabilities and meet the needs of the priority population segments. To assess vulnerability three dimensions must be considered: the social, the individual and the programmatic dimension (AYRES, 2003; 2007).

Vulnerabilities must be analyzed in the light of individual dimensions and taking into account the social place each individual occupies. When dealing with vulnerabilities from a social and programmatic perspective we allow the integration of the health situation and the various possibilities of intervention without forgetting the participation of the individuals. In addition to social relations, power relations in the context of women's vulnerability emerge as a strong trigger for the epidemic progression among women and highlight how power relations in terms of sex and domination occur.

\section{Epidemic feminization}

Epidemic feminization started in the 1980 ' when the focus was on risk groups that included homosexuals, drug users and, later, sex professionals to whom the campaigns were directed. As we can see, women were not considered as part of the risk groups, conveying the false impression that the epidemic would not affect people outside these groups (PANARRA et $a l, 2017)$.

However, women were infected by the virus from the beginning, and in the 1990' an increase in the number of infected women with single and fix partners was observed. This dilemma and the pressure of feminist movements resulted in the recognition of the illness as epidemic and in the realization that focusing on the risk groups was less important than understanding their behaviors and vulnerabilities (SILVA et al, 2013). 
In Brazil, according to the data collected until July 2013, 686,478 AIDS cases were notified. From those 445,197 (64.9\%) were males and 241,223 (35.1\%) were females. In 1985 there were 26 male cases to 01 female case; in 2005 the lowest value was 1.4 to 01, and in 2012 the relation was 1.7 cases in men and 01 in women. From the beginning of the epidemic to the present the number of infected women increased, while the number of infected men decreased almost equaling the former which indicates the feminization pattern of the epidemic (BRASIL, 2013).

According to the Ministry of Health, women are infected due to lack of information, especially during antenatal appointments, which contributes to the gradual HIV/AIDS contamination by vertical transmission or breastfeeding. From 1980 to June 2013 14,464 new cases of vertical transmission were registered. The rate varies from 01 to $20 \%$ depending on the control actions adopted by the STD/AIDS National Program (BRASIL, 2013).

Panamarra et al. (2017) reports that the increase of HIV/AIDS infection among women results in significant changes in its epidemiologic profile, such as the increase of infected newborns and children due to vertical transmission.

\section{METHODOLOGY}

This study was qualitative and descriptive. Phenomenology (MERLEAU-PONTY, 2002) was used to understand women's perception of HIV contamination, for it allows to study the essence, perception and awareness by asking "how is it to be a..." and trying to capture the essence of the experienced world.

The study was carried out in the Centro de Testagem e Aconselhamento e Serviço de Atendimento Especializado Viva Vida (CTASAE) located in Santo Antônio de Jesus, BA, Brazil. The municipality is located in the Reconcavo Sul region, on the edge of the highway BR 101, 187 $\mathrm{km}$ away from the capital city of the state.

The participants of this study were 26 women whose inclusion criteria were being HIV/AIDS positive, > 18 years old, and agreeing to participate in the research by signing the Informed Consent Form (ICF). Women under 18 and those who did not sign the ICF were excluded.

The interviews were conducted at the CTASAE, which was considered a neutral environment free from family interference, from September to November 2014 on the day and at the time of the participants' medical appointment.

The sample size followed the concept of saturation, i.e. no further participants were interviewed when due to content repetition no further information could be collected.

Since the answers obtained during the interviews were manifold, they were organized in groups with similar characteristics previous to their analysis, which was based on vulnerabilities.

The present study followed the ethical aspects required in investigations with human beings as stated by resolution 466/12 of the National Health Council, and guaranteed secrecy and anonymity of the participants. The project was approved by the Ethics Committee of Bahia's State Department of Health (CEP-SESAB 630.243). 


\section{RESULTS AND DISCUSSION}

\section{Women's Profile}

The age of women living with HIV/AIDS varied between 18 and 60 years old. Fifteen women were in the 18-34 age bracket and 9 were 35 to 49 years old. With regard to the marital status, 12 women stated they were married, 7 said they were single, 4 were widows, one was divorced, and one was in a common-law marriage. In terms of color/race 13 women defined themselves as black, 10 as mulattos and 3 as white. Schooling is one of the most important indicators to determine the health level of a population. From the 26 interviewed women only 11 finished elementary school and 08 had a high school degree (Table 1).

For people living with HIV/AIDS religion helps them to cope with the disease, as shown by the answers collected during the interviews. The majority of women (17) were catholic, 07 evangelic, 01 belonged to candomblé ${ }^{1}$, and only one said she had no religion. When asked about their jobs, $08(30.8 \%)$ women said they were housewives and 05 (19.2\%) were farmers. As can be concluded from their professional profile, the interviewed women had low or no incomes. Twenty of them received the statutory minimum wage, 02 received more than the minimum wage, 02 less than the minimum wage and 02 had no income (Table 1).

The 26 interviewed women said they were heterosexual, and all reported having been sexually contaminated, not by drugs, transfusion or occupational accident. The time elapsed to discover the HIV status is important to assess the

\footnotetext{
${ }^{1}$ Afro-Brazilian religious community
}

patient's health profile. The sooner the HIV is diagnosed, the higher the chances of starting treatment before the onset of opportunistic infections. In the present study 14 (53.8\%) women had found out they were contaminated six months to a year before the interview, and with regard to the immunologic status, 18 women had AIDS and 8 were HIV-infected (Table 2).

The HIV/AIDS epidemic requires a thorough research on all the factors that directly affect women's vulnerability in different ways. Thus, in the next section we will discuss the social, individual and programmatic dimensions related to women's vulnerability in order to better understand HIV/AIDS from a phenomenological point of view in the Recôncavo da Bahia.

Table 1 - Profile of women living with HIV/AIDS in the Centro de Testagem e Aconselhamento e Serviço de Atendimento Especializado em Santo Antônio de Jesus - BA, 2014.

\begin{tabular}{ll}
\hline VARIABLES & NUMBER (\%) \\
\hline AGE GROUP & $15(57.7 \%)$ \\
$18-14$ & $09(34.6 \%)$ \\
$35-39$ & $02(07.7 \%)$ \\
$50-60$ & \\
COLOR/RACE & $13(50.0 \%)$ \\
Black & $10(38.5 \%)$ \\
Mulattos & $03(11.5 \%)$ \\
White & \\
MARITAL STATUS & $12(46.1 \%)$ \\
Married & $07(26.9 \%)$ \\
Single & $04(15.4 \%)$ \\
Widowed & $01(03.8 \%)$ \\
Divorced & $01(03.8 \%)$ \\
Common-law marriage & \\
SCHOOLING & $11(42.3 \%)$ \\
Elementary School & $08(30.8 \%)$ \\
High School Degree & $03(11.5 \%)$ \\
Illiterate & $02(07.7 \%)$ \\
Did not finish elementary & \\
school & \\
Did not finish high school & $01(03.8 \%)$ \\
University Degree & $01(03.8 \%)$ \\
RELIGION & \\
Catholic & $17(65.4 \%)$ \\
Evangelic & $07(26.9 \%)$ \\
Candomblé & $01(03.8 \%)$ \\
\end{tabular}




$\begin{array}{ll}\text { No religion } & 01(03.8 \%) \\ \text { OCCUPATION } & 08(30.8 \%) \\ \text { Housewife } & 05(19.2 \%) \\ \text { Farmer } & 04(15.4 \%) \\ \text { Retired } & 02(07.7 \%) \\ \text { Saleswoman } & 02(07.7 \%) \\ \text { Unemployed } & 01(03.8 \%) \\ \text { Shellfish Collector } & 01(03.8 \%) \\ \text { Maid } & 01(03.8 \%) \\ \text { Hairdresser } & 01(03.8 \%) \\ \text { Waitress } & 01(03.8 \%) \\ \text { Student } & \\ \text { HOUSEHOLD INCOME } & 20(07.9 \%) \\ \text { MW (Minimum Wage) } & 02(07.7 \%) \\ \text { Less MW* } & 02(07.7 \%) \\ \text { More MW* } & 02(07.7 \%) \\ \text { No income } & \end{array}$

*MW: than the minimum wage;

Table 2 - Sexual practice, time elapsed since the pathology was diagnosed and immune status of women interviewed in the Centro de Testagem e Aconselhamento e Serviço de Atendimento Especializado in Santo Antônio de Jesus - BA, 2014.

\begin{tabular}{lc}
\hline VARIABLE & NUMBER (\%) \\
\hline SEXUAL ORIENTATION & \\
Heterossexual & $26(100.0 \%)$ \\
TRANSMISSION & $26(100.0 \%)$ \\
Sexual & \\
TIME ELAPSED SINCE & THE PATHOLOGY \\
WAS DIAGNOSED & $14(53.8 \%)$ \\
6 months to a year & $05(19.2 \%)$ \\
2 to 3 years & $05(19.2 \%)$ \\
4 to 5 years & $02(07.7 \%)$ \\
More than 5 years & \\
IMMUNE STATUS & $18(69.2 \%)$ \\
Aids & $08(30.8 \%)$ \\
HIV & \\
\hline
\end{tabular}

\section{Individual vulnerability}

In the present study the speech of the interviewed women reveals that trust, romanticism and genre power ratifies individual vulnerability:

Trust got me the disease. Sometimes it is the woman who is adulterous and infects the man, and sometimes it is the other way round, the man is adulterous and infects the woman, as was my case. I got it from him, I didn't know. But then I had a CVA and the doctors told me. But he was my husband, I loved him and thought there was no need for protection (E 01).

Both the man and the woman can be contaminated, because most people don't care about prevention, don't use condoms. I'm a widow, and today I have a different partner and I can use condoms. But before him, when I was married, I thought that for the fact of being married I was protected, there was no risk of getting HIV (E07).

I suffered a great deal. I thought he was faithful and I trusted him. It was a shock. You stay at home, you think you are protected, that your husband is loyal. But temptation is powerful and things happen (E 20).

As can be seen from the statements, it is more difficult for women involved in ongoing and steady relationships to take into account the risk of acquiring the virus. It is necessary to emphasize that women's vulnerability to HIV/AIDS is an evident fact, as shown by the increase of contaminated women. Genre relationships are relations of power and the place women occupy in them has been historically unequal, resulting in a growing number of contaminated women when compared to men.

Despite the conventional believe that women are also vulnerable from a biological point of view, it is important to understand that this vulnerability is the result of individual choices and of the type of relationship established with 
their partners. From the women testimonies we may conclude that the couple's confidence and intimacy justify the individual vulnerability of women.

\section{Social vulnerability}

With regard to sexual vulnerability, it is necessary to admit that black women's vulnerability increases when factors, such as education, poverty, housing, and individual and collective perception converge to increase the HIV contamination risk.

Not only feminization, but also impoverishment and blackening are characteristics of the HIV/AIDS epidemic. The association of genre relations, race/color, schooling, monthly income, and housing are factors that act upon women's vulnerability to health problems that impair their exercise of citizenship and their empowerment in genre relationships.

As stated by the participants, being ill is associated to death, discrimination, loss and limitations. Guilt for being contaminated, shame of being HIV positive and punishment are recurrent feelings among the women in this study, because they believe the infection is the result of inappropriate social behavior. Once again, there is an emotional load tied to the feeling of shame for being HIV positive. The feelings of shame, sadness and suffering are explicit in the women's discourse:

I'm afraid of dying and living my children alone, of lying in bed, of having everybody looking at me and thinking I'm HIV positive as if it were written on my forehead. (E10).
The health authorities of my city don't know, nobody knows, nobody needs to know [...] I don't tell anybody, I'm ashamed and nobody needs to know (E 02).

Being HIV positive is an immense weigh, I don't know what to say, it's very sad. The health authorities of my municipality know about my situation, and I don't want people to know about my illness, I'm afraid and ashamed (E07).

The women's statements depict the patients' anguish and fear of death, which might be explained by the fact that HIV/AIDS can still not be cured and has a very negative representation in society as a whole. Even with the improvement of anti-retroviral therapy and patient follow-ups, death still represents a fragility and uncertainty for HIV/AIDS patients.

Besides the individual issues, prejudice affects the way these women think of family, especially children, and people around. The role of prejudice in the women's daily life becomes evident in their statements:

I suffer prejudice, I have prejudices against myself. I'm afraid of my daughter wearing my shoes, I'm afraid of people's prejudice against me and against my daughter for having a mother like me (E01).

Prejudice is bigger than the illness, I even have prejudices against myself. I'm afraid, I don't talk to anybody about the illness. Anyway, nobody needs to know. Society 
sees the HIV positive patient as someone who deserves it (E02).

Having HIV makes my soul feel weak. Everybody has prejudices, even we, the own patient doesn't accept herself(E18).

From the patients' statements it may be concluded that the HIV positive diagnosis changed their life and the life of their relatives. Looking back at the HIV/AIDS epidemic, we realize it was accompanied by discrimination and prejudice mainly because it was associated to homosexuals and promiscuity. Despite the profile change of people living with HIV/AIDS prejudice, stigma and discrimination prevail, making the patients feel anguish, fear, shame, anxiety and depression.

\section{Programmatic Vulnerability}

The programmatic vulnerability dimension includes several indicators, such as health and social service access, service organization, relation of the users with the service and the health professionals, and prevention actions.

This dimension is also related to HIV/AIDS public policies, action planning and managing, authority commitment, effectively proposed and implemented actions, long-lasting programs with appropriate and fixed budgets, program feedback and evaluation, links between the institutions and the organized civil society, and intervention programs against prejudices and stigma that affect people living with HIV/AIDS.

When analyzing the programmatic vulnerability, other issues must be considered, such as the government commitment with the epidemic, with education and preventive actions; investments and financing of assistance and preventive actions; qualified human resources and facilities; high quality program management and monitoring; action continuity and sustainability among others.

Today Brazilian policies concerning HIV/AIDS patients are based on the constitutional principles of universality, comprehensiveness and equanimity. However, the speech of the interviewed women showed that access to information before and after diagnosis and to medical procedures is far below their expectations:

When I found out I was ill, the service didn't explain to me how the follow up was going to be. I think they should give more support to people with HIV, take better care of us. Getting an appointment to have a test done takes ages. I can't make the appointment I need and sometimes I have the impression that people without the disease get the appointment before I do $(\mathrm{E}$ $01)$.

Getting help from the health authorities was humiliating, they even wanted a monthly TFD (out of home treatment) report. At the beginning they wanted me to have the CID (International Statistical Classification of Diseases and Related Health Problems) and I told them if they asked for that document again, I would go after my rights (E 13). 
To come to the appointment I have to take a car that leaves in the morning, even if the appointment is in the afternoon. And sometimes I have the appointment, but there is no car to come here (E 26).

Women's assistance policies concerning STD/HIV/AIDS are important in the context of our study not only due to the divergent relations between the epidemic and genre relations, but also because of the knowledge improvement about the relations among genre, sexuality and health that resulted from the epidemic. However, the analysis of the interviewed women discourse regarding the rights of people living with HIV/AIDS reveals that they know little or nothing about the subject which reinforces their programmatic vulnerability:

I don't know the rights I have (E 01). I don't know the rights a HIV woman has, I just know my rights about delivery (E 02). I don't know and I think the politicians don't want us to know, so they have less work to do (E 22).

The women's testimonies clearly show that they are unaware of the health care policies for people living with HIV/AIDS. This lack of knowledge has a direct and negative effect on the vulnerabilities, the more so in the case of poor women. Thus, it is of the utmost importance to change the present scenario in order to face the epidemic's feminization.

Brazil stands out internationally with regard to the implementation of health care and preventive actions promoted by governmental and non-governmental institutions. It can't be denied that the struggle to achieve the recognition of the rights of people living with HIV/AIDS was essential to reduce social, individual and programmatic vulnerability. Notwithstanding, there are blanks to be filled and women living with HIV/AIDS must be aware of their rights. It is important to notice that the most vulnerable population is still unaware of public policies and has difficulties getting access to public health services, assistance, information and education.

The women's profile in our research is in accordance with the results of recent epidemiologic studies on the disease. For Santos (2014) it is important, when analyzing the profile of young adult women, to keep in mind that as they are in the reproductive stage, the infection might cause not only morbidity and mortality but also vertical transmission.

With regard to marital status, it reflects the epidemic profile change, namely, women in stable unions that are infected because they are unable to negotiate the use of condoms and/or because they believe their marital status turns them immune to diseases (OLTRAMARI; OTTO, 2006).

In the health-disease process color recognition is important, since historically afrodescendants were deprived of essential services, such as education, which results in discrimination, racism and social inequalities that directly affect their quality of life. And as it is well-known, low level of education is an important factor, because it limits the access to information on which the HIV/AIDS prevention attitudes depend (LOGIE $e t$ $a l, 2016)$. 
Still according to Santos (2014), level of education, social origin and physical and emotional conditions may contribute to exclude afro descendants from the labor market or force them into informal jobs, all of which results in a lower income.

Poor social backgrounds affect people's life quality, especially in the case of HIV/AIDS, and increase the health risks associated to social and economic factors (BRANTLEY et al, 2017). According to Teixeira (2009) religion is a strong alternative to face the disease, because it gives emotional support by lessening suffering and anguish.

When considering heterosexual relations, the decision of using condoms is in the majority of cases made by the man, thus revealing genre asymmetries in the relations between men and women (MADUREIRA; TRENTINI, 2008).

Mean survival time of people living with HIV/AIDS has increased in the last years probably due to a number of factor among which we might mention the development of new therapeutic and prophylactic approaches, the knowledge improvement about the disease (BRASIL, 2001), and also the general reduction of the time elapsed between the infection and the diagnosis.

Individual vulnerability encompasses a cognitive and a behavioral dimension. Cognitive factors are related to the access to HIV/AIDS information, to the amount and quality of the information available, and to the individual's capacity to process the information and incorporate it in his/her daily life. Among the behavioral factors we may mention emotional development (risk perception and attitudes toward self-protection) and personal skills, such as the negotiation of safe sex practices and condom use (AYRES et al, 2003).

Understanding vulnerability is mandatory to understand the spread of HIV/AIDS among women, since there is an intersection of individual and subjective behaviors and experiences linked to sexuality, faithfulness, prejudices, freedom and death permeated by unequal genre and power relations (MADUREIRA; TRENTINI, 2008).

Feminine submission indicates an asymmetric relation that opens up space for men to wield their power, which is characterized by a set of actions chosen among a set of possible actions. This power acts on the possibility field where the active subject behavior is inscribed, inhibiting or preventing a way of acting, and it is present in the relations where one partner tries to direct the other (PARKER, 2001).

Another aggravating factor is the association between sex and passion or love in stable relations which weakens the negotiation power of condom use, because the woman feels protected by the trust in her partner (BRANTLEY et al, 2017).

Marital status is important when considering HIV/AIDS infection. Filipe et al. (2005) explain that women, when married or in steady relationships, do not feel at risk, because they see monogamy as a protective factor which gives them a false impression of safety.

The submission and oppression process which women underwent and still undergo consolidates itself on hierarchic and asymmetric power relations of different orders and intensities that silence their voices. Thus, we might conclude that genre inequality is the triggering factor of 
marital vulnerability in which sexual emotional relationships result in women's constant submission to male patterns (GUILHEM; AZEVEDO, 2008).

For women in marital or steady relationships the concept of trusting the partner is not related to fidelity, but to the belief that if he does not wear condoms with his wife it is because he uses them in extramarital relationships. The acceptance of condom use in extramarital relationships goes beyond the acceptance of unfaithfulness, because the protection against STDs allows silence and invisibility and, in opposition to what is said, it favors the contamination of monogamous women (GARCIA; SOUZA, 2010).

It is frequently observed that the power relationships that affect the social relations of genre are the cause of the difficulties women face to negotiate condom use with their partners, as well as the use of their own bodies which leaves them vulnerable to sexual transmitted diseases (MADUREIRA; TRENTINI, 2008).

With regard to social vulnerability, the HIV representation is strongly related to moral and material damage. In social interactions the prevailing feelings include fear of judgment, abandonment, social identity exposure, helplessness, guilt for being ill, escape, omission, clandestinity, exclusion and suicide all of which are entwined with a prejudiced society (ALMEIDA; LABRONICI, 2007).

Attitude and emotional reactions to death are human and do not depend only on cultural education, but also on situational knowledge. When facing death, patients may experience negation, hatred, depression and sometimes acceptance (SILVA et al, 2013). Positive diagnosis also affects the family structure and may lead to closeness or to estrangement (BARBIERI; MACHADO; FIGUEIREDO, 2005).

With regard to stigma, Ayres (2003) divided it in two categories: the felt stigma and the suffered stigma. The former, generated by the own patient, results in depreciation and/or exclusion and may cause shame, fear, anxiety and depression. The latter is represented by social actions, such as attitudes and omissions that cause damage to or limit benefits of the stigmatized person.

In terms of social relations, attitudes towards HIV-positive people must be understood in the social context in which they live. Attitudes that indicate discrimination, prejudice and stigma must be condemned (LOGIE et al, 2016).

Women living with HIV/AIDS need psychological support to work on the fear of death, guilt and shame. Relatives also need support in order to deconstruct stereotypes, prejudices and estrangement that might be present in the core of the family (BARBIERI; MACHADO; FIGUEIREDO, 2005).

As could be observed from the women's statements, access to the health services is difficult and impairs regular ongoing care, although free health care service and free access to medicines are guaranteed by law. In fact, free access is the key to the success of the program which has improved life expectancy and life quality. On the other hand, the lack of guarantees concerning the access to health care services fails to comply with the law (BRANTLEY et al, 2017). 
When in 1988 the new Federal Brazilian Constitution guaranteed equal rights for men and women, a political, institutional and legal milestone in women's rights was reached. That change was made possible thanks to the pressure of feminist and women's movements known as "lipstick lobby", who maintained a watchful eye throughout the constitutional reformulation (BRASIL, 2007).

From the women's health perspective, the proposed action plan must be guaranteed in order to promote the improvement of health and life conditions, by ensuring women's legal rights and widening the access to prevention, assistance and health recovery services nationwide. The action plan must also contribute to feminine morbidity and mortality reduction especially when they are the result of avoidable causes, in every life cycle and in all population groups without any kind of discrimination. It should also extend, qualify and humanize comprehensive care for women in the Unified Health System - SUS (CASTANHA et al, 2007).

\section{FINAL CONSIDERATIONS}

Social vulnerability affects the group and is related to color/race, marital status, schooling, religion, occupation and family income. But we should not forget that genre affects social vulnerability, because even after the social struggle for feminine empowerment, when the relationships involve sexuality and marital situations, women's dependence in relation to men reflects the asymmetries that weaken women's HIV/AIDS prevention attitudes, since they passively accept their partners' decisions.
The vulnerability dimensions of this group are interdependent and, consequently, the degree of individual vulnerability of these women is high and strongly affected by genre relationships. The HIV/AIDS epidemic's evolution clearly demonstrates women's vulnerability who, despite the feminine conquests of the last centuries, still engage in asymmetric relations with regard to marital, sexual and social issues.

Although biology facilitates individual vulnerability, it is not crucial. The decisive factors for contamination are power asymmetries related to genre. In the imagery of the interviewed women, love protects them from HIV contamination and thus the responsibility of care and prevention is transferred to the male partner.

This fact reinforces the group's vulnerability which has no risk perception, since the values and believes in the marital relation or in the partner are affected by the fear of recognizing that the partner could be unfaithful, not knowing the partner's previous sexual life, or showing no trust. These issues may be considered determinant for avoiding safe sex and allowing contamination.

We can't deny the existence of programmatic vulnerability. However, with regard to health and group public policies genre actions concerning men and women in their cultural and regional diversity should be the primary focus, because the HIV/AIDS epidemic has multiple faces and contexts.

We would like to emphasize that programmatic vulnerability is a strong iniquity indicator for this group, since they are not offered - or the offer is insufficient - the right to health and access to treatment. In terms of vulnerability 
women's empowerment concerning their place and position in genre relationships is mandatory and urgent.

It is of the utmost importance that the interventions in this group take into account not only the knowledge about the infection, but also genre issues, moral values, risk self-perception and social and economic matters. To reach these objectives prevention strategies must be adopted to address the epidemic. Moreover, the women's physical, psychological and cultural needs should be met.

\section{REFERENCES}

ALMEIDA, MRCB; LABRONICI, LM. A trajetória silenciosa de pessoas portadoras do HIV contada pela história oral. Ciênc. Saúde Coletiva. 2007. [acesso em 10 jan 2015]. 12 (1). Disponível em: < http://www.scielo.br/scielo.php?script=sci_arttext\&pid $=\mathrm{S} 1413-81232007000100030$

AYRES, JRCM. Epidemiologia, promoção da saúde e o paradoxo do risco. Revista Brasileira de Epidemiologia. 2003.

[acesso em 07 jun 2015]. 5 (supl.1): 28-42 Disponível em: <

http://www.scielo.br/scielo.php?script=sci arttext\&pid $=\mathrm{S} 1415-790 \mathrm{X} 2002000400005$

AYRES, JRCM. et al. O conceito de vulnerabilidade e as práticas de saúde: novas perspectivas e desafios. In: CZERESINA, D.; FREITAS, CM. (org.). Promoção da Saúde: conceitos, reflexões, tendências. Rio de Janeiro: Editora Fiocruz, 2003..

[acesso em 17 fev 2016]. 117-140. Disponível em: < http://www.scielo.br/scielo.php?script=sci_arttext\&pid $=\mathrm{S} 1413-81232007000100030$

AYRES, JCRM. Uma concepção hermenêutica de saúde. Physis: Revista de Saúde Coletiva. 2007. [acesso em 19 fev 2016]. 17 (1). Disponível em: < http://www.scielo.br/scielo.php?pid=S0103$73312007000100004 \&$ script $=$ sci abstract\&t $\ln g=p t$

BARBIERI, AL; MACHADO, AA.; FIGUEIREDO, MAC. Estudo qualitativo de crenças relativas aos cuidados domiciliares e à morte entre familiares de portadores do HIV/AIDS e câncer. Paideia, Ribeirão Preto. 2005. [acesso em $10 \mathrm{dez} 2016$ ]. 15 (32): 427-432. Disponível em: < http://www.scielo.br/scielo.php?pid=S0103$\underline{863 \times 2005000300012 \& \text { script }=\text { sci abstract\&tlng }=\mathrm{pt}}$

BASTOS, FIA feminização da AIDS no Brasil: determinantes estruturais e alternativas de enfrentamento. C. ABIA: Saúde Sexual e Reprodutiva, Rio de Janeiro, n. 03, 2000.

BRANTLEY, ML. et al. Identifying patterns of social and economic hardship among structurally vulnerable women: a latent class analysis of HIV/STI risk. AIDS and behavior. 2017.

[acesso em 25 out 2015]. 21 (10): 3047-3056.

Disponível em: <

https://www.ncbi.nlm.nih.gov/pubmed/28138802

BRASIL. Ministério da Saúde. Boletim

Epidemiológico AIDS/DST. Secretaria de Vigilância em Saúde. Departamento de DST, AIDS e Hepatites

Virais. Brasília: Ministério da Saúde, n.1, p. 64, 2013.

BRASIL. Ministério da Saúde. Secretaria de Vigilância em Saúde. Programa Nacional de DST e Aids. Plano integrado de enfrentamento da feminização da epidemia de Aids e outras DST. Brasília, 2007. [acesso em 15 dez 2015]Disponível em:

<http://www.aids.gov.br.

BRASIL. Portaria MS/GM nº 95 . Regionalização da assistência à saúde: aprofundando a descentralização com equidade no acesso. Norma operacional da assistência à saúde NOAS-SUS 01/01. Diário Oficial da União 2001; 29 jan.

CASTANHA, AR. et al. Avaliação de qualidade de vida em soropositivos para o HIV. Estudos de Psicologia. 2007.

[acesso em 01 ago 2015]. 24 (1):23-31. Disponível em: <http://www.scielo.br/pdf/estps/v24n1/v24n1a03.pdf

FILIPE, EMV. et al. Sexual orientation, use of drugs and risk perception among HIV-positive men in São Paulo, Brasil. International Journal of STD \& Aids. 2005.

[acesso em 30 set 2014]. 16 (1): 56-60. Disponível em: $<$ https://www.ncbi.nlm.nih.gov/pubmed/15705275

GARCIA, S.; SOUZA, FM. Vulnerabilidades ao HIV/Aids no Contexto Brasileiro: iniquidades de gênero, raça e geração. Saude Soc.[online]. 2010. [acesso em 06 set 2014]. 19 (supl.2): 9-20. Disponível em: <

http://www.scielo.br/scielo.php?script=sci_arttext\&pid $=\mathrm{S} 0104-12902010000600003$

GUILHEM, D.; AZEVEDO, AF. Bioética e gênero: moralidades e vulnerabilidade feminina no contexto da Aids. Revista Bioética. 2008. 
[acesso em 10 jun 2015]. 16 (2): 229-240. Disponível em: <

http://revistabioetica.cfm.org.br/index.php/revista bioe $\underline{\text { tica/article/view/70 }}$

GUEDES, TG. et al. Vulnerabilidade a DST/HIV/AIDS. DST-J bras Doenças Sex Transm. 2009.

[acesso em 10 jan 2015]. 21 (3): 118-123. Disponível em: < http://www.dst.uff.br/revista21-3-2009/4$\underline{\text { Mulheres-Monogamicas.pdf }}$

LOGIE, CH. et al. A Structural Equation Model of HIV-Related Stigma, Racial Discrimination, Housing Insecurity and Wellbeing among African and Caribbean Black Women Living with HIV in Ontario, Canada. PLoS ONE.2016.

[acesso em $11 \mathrm{dez} 2016] .11$ (9). Disponível em: < http://journals.plos.org/plosone/article?id=10.1371/jour nal.pone. 0162826

MADUREIRA, VSF.; TRENTINI, M. Relações de poder na vida conjugal e prevenção da AIDS. Rev. bras. Enferm. 2008.

[acesso em 21 jul 2015]. 61 (5): 637-642. Disponível em: <

http://www.scielo.br/scielo.php?script=sci_abstract\&pi $\mathrm{d}=\mathrm{S} 0034-$

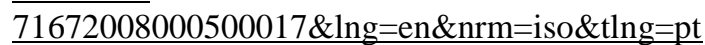

MANN, J.; TARANTOLA, D.; NETTER, T. (orgs.) A aids no mundo. Rio de Janeiro: Relume-Dumará, 1993.

MERLAU-PONTY, M. Phenomenology of perception. London, UK: Routledge, 2002.

NEVES, FRAL. O aconselhamento para realização da sorologia anti-hiv em gestantes. DST J. Bras Doenças Sex Transm. 2009.

[acesso em 31 ago 2015]. 21 (3): 111-117. Disponível em: <

http://www.scielo.br/scielo.php?script=sci_arttext\&pid $=\mathrm{S} 1414-81452008000400004$

OLTRAMARI, LC.; OTTO, LS. Conjugalidade e AIDS: um estudo sobre infecção entre casais. Psicol Soc. 2006.

[acesso em 30 mar 2015]. 18 (3): 55-61. Disponível em: < http://www.scielo.br/scielo.php?pid=S0102$\underline{71822006000300008 \& \text { script }=\text { sci_abstract \&t } \operatorname{lng}=\mathrm{pt}}$

PAIVA, V.et al. Capacitando profissionais e ativistas para avaliar projetos de prevenção do HIV e de Aids. Revista Saúde Pública. 2002.

[acesso em 14 mar 2016]. 36 (supl. 4): 4-11.

Disponível em: <

https://www.scielosp.org/scielo.php?script=sci_arttext \&pid=S0034
PANARRA, BACS. et al. Vítimas e culpadas: representações sociais sobre mulheres que vivem com HIV. Rev Cuid. 2017.

[acesso em $11 \mathrm{dez} 2017$ ]. 8 (3): 1887-1898. Disponível em: <

https://www.revistacuidarte.org/index.php/cuidarte/arti cle/view/451

PARKER, R. Sexuality, Culture, and Power in HIV/AIDS Research. Annual Review of Anthropolog. 2001.

[acesso em 10 jan 2017]. 30: 163-179. Disponível em: <http://www.annualreviews.org/doi/abs/10.1146/annur ev.anthro.30.1.163

SANTOS, AN. Representações sociais de mulheres que vivem com o HIV/aids sobre aids, HIV e cuidado de enfermagem. [Tese de Doutorado]. Universidade Federal da Bahia. Escola de Enfermagem, 247 p. 2014. [acesso em 25 jun 2015]

Disponível em: https://repositorio.ufba.br

SILVA, SED. et al. O processo morte/morrer de pacientes fora de possibilidade atuais de cura: uma revisão integrativa. Revista Eletrônica Gestão \& Saúde. 2013.

[acesso em 04 jan 2015]. 4 (2): 2311-2325. Disponível em: $<$

http://periodicos.unb.br/index.php/rgs/article/view/229 $\underline{56}$

TEIXEIRA, M. A. Soropositividade de mulheres para os vírus HIV e HTLV: significados do contágio do leite materno. Salvador. [Tese de Doutorado]. Escola de Enfermagem da Universidade Federal da Bahia, 2009. [acesso em 15 maio 2016]. Disponível em: https://repositorio.ufba.br

\section{Núbia Cristina Rocha Passos}

Enfermeira, Mestre em Desenvolvimento Regional e Meio Ambiente da Faculdade Maria Milza (FAMAM). Docente da Faculdade de Ciências Empresariais (FACEMP). Bolsista da Fundação de Amparo a Pesquisa da Bahia (FAPESB).

\section{Larissa Rolim Borges-Paluch}

Doutora em Ciências Biológicas - UFPR. Docente do Mestrado em Desenvolvimento Regional e Meio Ambiente da FAMAM.

\section{Elizabete Rodrigues da Silva}

Doutora em Estudos Interdisciplinares sobre Mulheres, Gênero e Feminismo - PPG/NEIM. Coordenadora e Docente do Mestrado em Desenvolvimento Regional da FAMAM.

\section{Liliany Santana da Silva}

Enfermeira Sanitarista, Mestre em Desenvolvimento Regional e Meio Ambiente da FAMAM. Docente da FAMAM. 